\title{
INFLUENCE OF PHOSPHOLIPID-CONTAINING ADDITIVES ON THE FUNCTIONAL CONDITION OF ORGANS AND SYSTEMS OF MICE
}

\author{
V. A. GRYSHCHENKO, Doctor of Veterinary Sciences, Professor \\ Department of Animal Biochemistry and Physiology \\ named after Academician M. F. Gulyi, \\ https://orcid.org/0000-0001-6601-1392 \\ National University of Life and Environmental Sciences of Ukraine, Kyiv, Ukraine \\ E-mail: viktoriya_004@ukr.net
}

\begin{abstract}
Numerous studies in experiments on laboratory animals and in clinical practice have confirmed the positive effect of essential phospholipids on the structural organization of cell membranes, intracellular metabolism, mitochondrial function, antioxidant processes, which explains the active use of phospholipid-containing drugs in hepato- and enteropathologies, cardiovascular diseases, etc. The raw material of animal origin, in particular milk, which is a safe source of biologically active substances, has a structural similarity with phospholipids of mammalian tissues. Based on them, a biologically active additive (BAA) "FLP-MD" was created, which is characterized by membranotropic properties and reparative effect. The aim of this work was to investigate the biological effect of the liposomal form of BAA "FLP-MD" based on milk phospholipids on the body of clinically healthy laboratory mice.

Determination of the toxicity of phospholipid-containing BAA "FLP-MD" was performed on mice of the CBA line. The duration of the experiment was 16 days. The results of the studies indicate a probable increase in body weight of mice of the CBA line after the 10th day of intragastric administration of $1 \%$ solution of liposomal form of BAA "FLP-MD".

As a result of the study of biochemical parameters of plasma / native blood, the absence of toxic effects of the liposomal form of BAA "FLP-MD" on the functional state of the body of mice was set. Morphological parameters of peripheral blood in these animals did not change significantly. According to the results of microscopic studies, no negative effect of the liposomal form of BAA "FLP-MD" on the structure microstructure of the mucous membrane of the gastrointestinal tract was found.

Therefore, the components of BAA "FLP-MD" do not adversely affect the functional state of organs and systems of laboratory mice and do not show a toxic effect, which allows it to be recommended for use in veterinary medicine as a means of rehabilitation therapy.
\end{abstract}

Keywords: milk phospholipids, BAA "FLP-MD", laboratory mice of the CBA line, clinical, hematological and microscopic examinations, functional state of the organism 


\section{Introduction}

Now, the key role of structural and functional destabilization of cell membranes due to phospholipid deficiency, lipid peroxidation, and their hydrolysis in the pathogenesis of inflammatory, dystrophic and degenerative processes has been scientifically and experimentally proven (Solís-Calero et al., 2015; Gariani et al., 2017; Calitz et al., 2018). This indicates the feasibility of introducing reparative therapies in veterinary medicine and medicine, which include phospholipid-containing drugs, in particular, the most famous in the world - Essentiale ${ }^{\circledR}$ Forte N. Numerous studies in experiments on laboratory animals and when used in clinical practice have confirmed the positive effect of essential phospholipids on the structural organization of cell membranes, intracellular metabolism, the functional ability of mitochondria, antioxidant processes, and explains the active use of phospholipid-containing drugs in hepatopathology and enteropathology, cardiovascular diseases, the intoxication of the body, etc. (Bothra et al., 2018; Colombo et al., 2018; Yang et al., 2018; Zhang et al., 2018).

The structural similarities with phospholipids of mammalian tissues have raw materials of animal origin, in particular, obtained from milk, as well as a by-product of its processing - butterdish, which is a cheap and safe source of biologically active substances. Based on them, we created a biologically active additive (BAA) "FLP-MD", which is characterized by membrane-active properties and reparative effect of an action. Therefore, it is advisable to use reparative therapy in applied veterinary medicine, focused on the peculiarities of pathogenetic disorders, taking into account the natural potential and physiological ability of cells to self-restore lost functions, especially dam- aged intracellular structures - membrane systems. This approach, along with traditional therapy in the medical field, helps to reduce the economic damage from animal death, the occurrence of relapses and complications of relevant pathologies, as well as the solution of environmental, food. and biological safety problems.

\section{Analysis of recent research and publications}

Preventive medicine that studies the problems of common non-communicable diseases, based on the identification of risk factors for the disease. An urgent task is to assess the risk of developing a chronic process, the formation of which correlates with the duration of risk factors action and their intensity. A chronic pathological process is formed under the influence of risk factors for a long period. In this regard, to suspend it or achieve regression of the disease is possible only as a result of prolonged exposure to corrective factors while eliminating or attenuating the effects of negative factors. Inhibition of the progression of the pathological process and, especially, its reverse development is an extremely difficult task that requires the use of rehabilitation measures.

New rehabilitation technologies for rehabilitation treatment include endoecological rehabilitation aimed at improving the natural cavities and spaces formed by the serous and mucous membranes, endothelial structures, as well as the restoration of the extracellular and cellular structures (Gryshchenko et al., 2018). Currently, there are four levels of endoecological rehabilitation. Particularly noteworthy is the fourth level, which is aimed at stimulating cell regeneration and structural and functional restoration of cell formations: external and intracellular membranes, protoplasm, membrane receptors, nuclear 
structures. The task of the fourth level of rehabilitation is solved by correcting the diet of animals with biologically active substances of membranotropic action, local action of membranotropic drugs (Gula \& Margitich, 2009).

The criterion for assessing the effectiveness of endoecological rehabilitation of the fourth level can be methods that characterize the processes that occur in cell (biological) membranes. The membrane responds to external signals and induces the production of the corresponding metabolites by the cell; it is able to effectively rebuild in response to various factors. The physical state of the membrane is known to be determined by phospholipids, primarily phosphatidylcholine, phosphatidylethanolamine, and phosphatidylserine, which contain the bulk of the polyene fatty acids of the $\omega-6$ and $\omega-3$ structure (Gryshchenko, 2019; Sang-Chul \& Xuemin, 2020).

In the process of rehabilitation therapy at the fourth level of endoecological interaction, there is a directed regulation of cellular lipid metabolism, which is carried out through the enzymatic block of desaturation of fatty acids, as well as due to the stabilization of vasodilator function in the synthesis of eicosanoids (Gryshchenko et al., 2019). Moreover, the intensity of lipid modification of cell membranes depends on the depth and nature of the initial metabolic disorders. The fourth level will be especially effective in rehabilitation for years, but the effect can be seen on several generations of the rehabilitated.

Most drugs from the arsenal of humane and veterinary medicine are artificially synthesized. Along with the quick effect of their use, the development of severe complications is possible, it is extremely dangerous in case of complex clinical situations (Gryshchenko et al., 2019; Starr et al., 2019). The likelihood of side effects requires a deliberate and careful prescription of such drugs in each case of the disease. Often the risk of negative effects of synthetic drugs on a living organism limits the possibility of their appointment due to existing contraindications. The vast majority of such drugs has cumulative properties and, if the recommended therapeutic and preventive doses are not followed, produces a toxic effect on the body.

The unqualified prescription of drugs, especially synthetic ones, often causes the development of a "drug" disease. According to statistical materials, the "drug" disease is the cause of death of about 100,000 people and the cause of the development of serious diseases in 2,200,000 people a year, unfortunately, no such studies have been conducted on the situation with animals. In many cases of "drug" disease, life-threatening side effects are noted: cardiac arrhythmia, renal failure, internal bleeding, and a critical decrease in blood pressure.

The use of natural, environmentally friendly raw materials with low cost to create BAA of therapeutic and prophylactic action should help reduce the negative impact of enteropathology on the health status of animals and the formation of their productive qualities (Tomchuk et al., 2019).

So, modern pharmaceutical production focuses on the search for new, efficient, environmentally friendly, and at the same time more cost-effective technologies; as a whole, it must solve an extremely important task - preserving human health and the environment. The components of dietary supplements can be various organic and mineral substances of natural origin, which, along with other properties of membranotropic action. These are phospholipids, essential fatty acids, amino acids, vitamins, etc. (Udut et al., 2013). The aim of the work was to investigate the 
biological effect of the liposomal form of BAA "FLP-MD" based on milk phospholipids on the body of clinically healthy laboratory mice.

\section{Materials and methods of research}

All manipulations with rats were carried out in accordance with the requirements of the European Convention for the Protection of Vertebrate Animals used for experimental and scientific purposes (Strasbourg, 1986), the Law of Ukraine "On the Protection of Animals from Cruelty” № 3447 from 02/21/2006, which was confirmed by the conclusion of the Bioethics Commission of the National University of Life and Environmental Sciences of Ukraine, Kyiv, Ukraine.

The toxicity of the biologically active phospholipid-dietary supplement "FLPMD" was determined in laboratory conditions on CBA mice by oral administration. The duration of the observation period is 16 days (Vlizlo et al., 2012).

These tests are widely used by toxicologists as a relatively quick, uncomplicated, low-cost, and statistically reliable method for assessing the negative effects of drugs on objects such as laboratory animals.

The studies were conducted on laboratory mice of the CBA line obtained from healthy individuals of the vivarium of the Institute of Oncology of the Academy of Medical Sciences of Ukraine. Used experimental mice that reached puberty at the beginning of the experiments. Healthy individuals were selected, which had approximately the same size and weight, had never before been used in other laboratory studies and manipulations. The weight of the mice was monitored throughout the experiment. So, at the beginning of the experiment, males weighed $19-20 \mathrm{~g}$, females $-18-19 \mathrm{~g}$.
To study the biological properties of the phospholipid-containing dietary supplement "FLP-MD" groups of experimental animals were composed of ten mice (five of each sex). Mice were kept in five individuals in a separate cage.

The drug was fed to mice every day for 16 days. Animals of the experimental group were intragastrically injected with a $1 \%$ solution of phospholipid-containing BAA "FLP-MD" in the liposomal form at a dose of $13.5 \mathrm{mg} / \mathrm{kg}$ once a day. BAA "FLP-MD" is the author's development (Melnychuk et al., 2009), which includes a complex of milk phospholipids (nipples) that have a fatty acid spectrum natural for mammalian cell membranes, a mixture of unsaturated fatty acids (oleic, linoleic, linolenic), obtained with linseed oil, and antioxidants (vitamins A and E). The control group included intact animals injected per os with an equivalent volume of distilled water. After administration of the test substance, the mice had free access to food and water. Food intake was monitored by both test and control mice.

We observed changes in the general condition of the animals, the presence of symptoms of intoxication. Every 24 hours of the experiment, the mice were weighed and the amount of feed consumed was monitored. After the experiment, the mice were decapitated under ether anesthesia, blood samples were taken for morphological and biochemical studies, stomach and intestine samples for microscopic studies. The blood was stabilized with heparin. Morphological (number of erythrocytes, leukocytes, platelets, leukogram) and physical (hematocrit, erythrocyte sedimentation rate, ESR) parameters of blood were calculated and measured by the method of Coulter on a veterinary hematology analyzer "Mindray BC 2800 Vet" (China) 
(Vlizlo et al., 2012). Hemoglobin content was determined in whole blood using the Analyzer Micro CC-20 Plus Auto HTI (USA) according to the instructions of the manufacturer. Biochemical indicators were determined by biochemical GBG Stat Fax 1904 Plus (Awareness Technology, Inc., Florida, USA) using chemicals purchased from DAC-SPECTROMED S.R.L. (Republic of Moldova). This device allowed to determine routinely the content of total protein, glucose; activity of enzymes e.g. aspartate transaminase (AST, EC 2.6.1.1), alanine transaminase (ALT, EC 2.6.1.2), alkaline phosphatase (ALP, EC 3.1.3.1) and lactate dehydrogenase (LDH, EC 1.1.1.27). Microscopic samples were stained with hematoxylin-eosin, blood smears according to Romanovsky-Giemsa.

Statistical data analysis was performed using software Statistica 6.0. Data confidence was estimated using Student t-criteria. Data were assumed as significant at $\mathrm{P}<0.05$.

\section{Results of the research and their discussion}

Throughout the experiment, the behavior of animals in the experimental group did not differ from that in mice of the control group. When assessing the appearance (condition of the skin, coat, mucous membranes) in mice of the experimental group, no differences were revealed compared with animals of the control group. After administration of the BAA "FLP-MD", no symptoms of intoxication (tremors, seizures, paresis, and paralysis) were observed in animals of the experimental group.

During visual observation in experimental animals, the frequency of urine output and defecation, as well as the color of urine and feces did not differ from those in the control group.
The dynamics of changes in the body weight of CBA mice of various groups are given in Table. 1. According to the table, when feeding a phospholipid-containing

BAA "FLP-MD" to mice for 16 days, a significant increase in the bodyweight of mice was observed after 10 days of experiment in both males and females.

The results of the study of morphological, biochemical, and physical parameters of the peripheral blood of mice treated with phospholipid-positive BAA "FLP-MD" for 16 days are presented in Table. 2.

According to the results presented in mice of the experimental group, the number of erythrocytes and the ESR decrease under the influence of phospholipids of the dietary supplement, which is better expressed in females (correspondingly from $(7.22 \pm 0.25) \times 10^{12} / \mathrm{L}$ to $(6.04 \pm 0.25) \times 10^{12} / \mathrm{L}$ and from $(1.6 \pm 0.24) \mathrm{mm} / \mathrm{h}$ to $(0.8 \pm 0.2) \mathrm{mm} / \mathrm{h}$, $\mathrm{P}<0.05)$. All other indicators of animals treated with BAA "FLP-MD" did not change significantly.

As a result of biochemical studies, which are presented in Table 3, when mice were fed phospholipids of milk in the form of liposomal BAA "FLP-MD" for 16 days, no significant changes in blood plasma parameters were found, with the exception of alanine transaminase (ALT, EC 2.6.1.2) in females.

The above allows us to conclude that there is no toxic effect of the components of the dietary supplement on the functional condition of the body.

The results of microscopic studies of the stomach and intestines. On the preparation of the esophagus in females of the experimental group, the transition of the stratified squamous epithelium of the esophagus into the glandular epithelium of the cardiac part of the stomach and the absence of cytological or structural 


\section{The average change in bodyweight of mice (g) over the experimental period} $(\mathrm{M} \pm \mathbf{m}, \mathbf{n}=\mathbf{5}$ in each group)

\begin{tabular}{|l|c|c|c|c|c|c|}
\hline \multirow{2}{*}{ Group of animals } & \multicolumn{5}{c|}{ Bodyweight $(\mathrm{g})$} \\
\cline { 3 - 7 } \multicolumn{2}{|c|}{} & 2 day & 5 day & 8 day & 10 day & 16 day \\
\hline $\begin{array}{l}\text { Experimental } \\
\text { Group }\end{array}$ & females & $17.7 \pm 0.3$ & $18.4 \pm 0.1$ & $18.6 \pm 0.3$ & $18.8 \pm 0.3^{*}$ & $19.0 \pm 0.3^{*}$ \\
\cline { 2 - 7 } & males & $19.5 \pm 0.4$ & $20.5 \pm 0.6$ & $21.1 \pm 0.6$ & $22.1 \pm 0.4^{*}$ & $22.9 \pm 0.3^{*}$ \\
\hline $\begin{array}{l}\text { Control } \\
\text { Group }\end{array}$ & females & $18.1 \pm 0.2$ & $18.6 \pm 0.3$ & $18.7 \pm 0.2$ & $18.9 \pm 0.2$ & $19.7 \pm 0.6$ \\
\cline { 2 - 7 } & males & $21.0 \pm 0.3$ & $22.0 \pm 0.6$ & $20.9 \pm 0.7$ & $20.9 \pm 1.0$ & $21.1 \pm 1.3$ \\
\hline
\end{tabular}

Note: ${ }^{*} \mathrm{P}<0.05$, compared with the initial data on the 2 nd day of the experiment in the context of the control groups.

changes in these organs are noted. In the esophagus, strata of the stratified epithelium are surrounded by keratin masses with foci of mineralization (dystrophic liming). Dystrophic liming indicates the antiquity of the mineralization process and is not a pathology. No structural changes were detected in the epithelial cells of the esophagus glands and the cardiac glands of the stomach. The muscular membrane with an active response of smooth muscle cells, the serous membrane is thickened with an active reaction of fibroblasts. At the intersection of the esophagus into the

2. Blood morphological, biochemical and physical parameters in experimental mice $(M \pm m, n=5$ in each group)

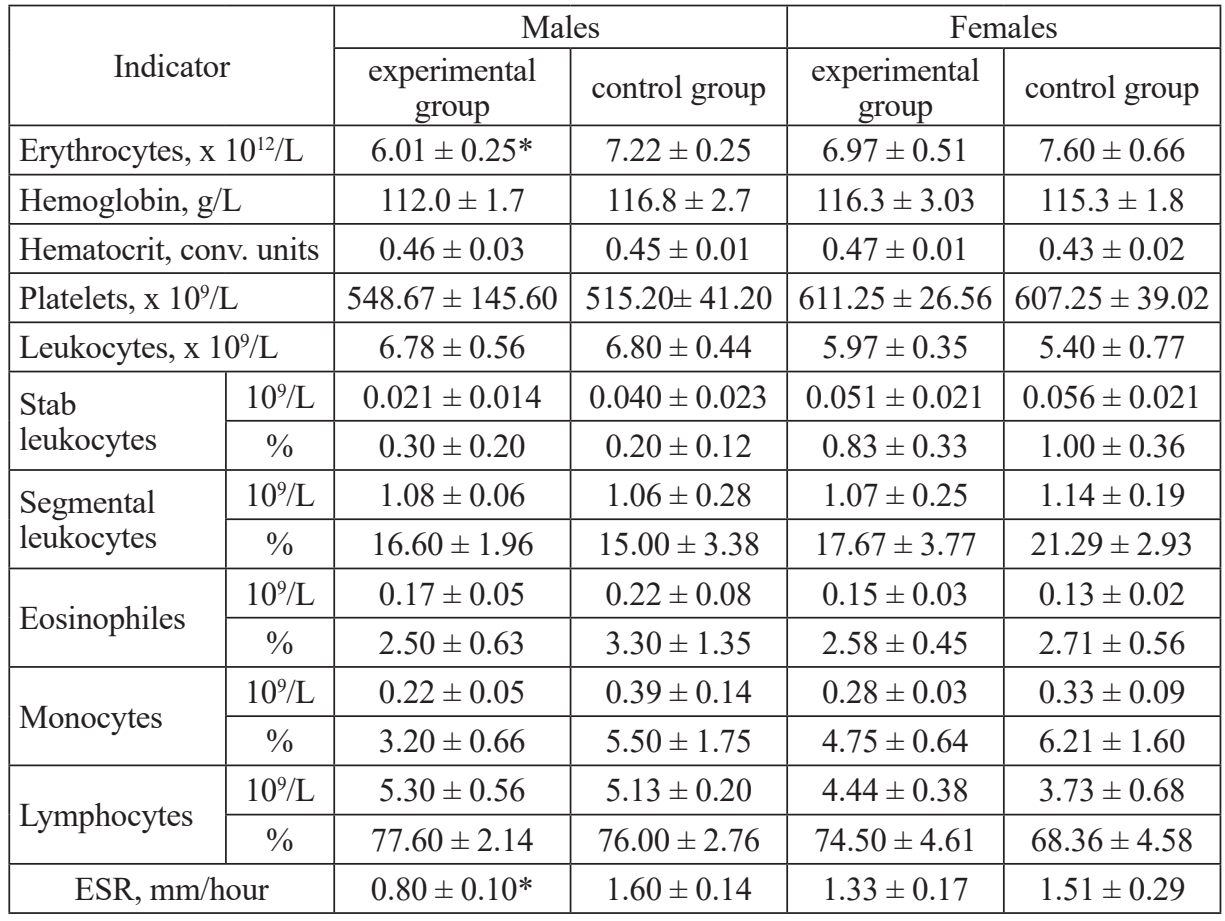

Note: $* \mathrm{P}<0.05$, the difference is significant compared with the control. 


\section{Blood plasma biochemical parameters in mice of different groups} $(\mathrm{M} \pm \mathrm{m}, \mathrm{n}=\mathbf{5}$ in each group)

\begin{tabular}{|l|c|c|c|c|}
\hline \multirow{2}{*}{ Indicator } & \multicolumn{2}{|c|}{ Males } & \multicolumn{2}{c|}{ Females } \\
\cline { 2 - 5 } & $\begin{array}{c}\text { experimental } \\
\text { group }\end{array}$ & control group & $\begin{array}{c}\text { experimental } \\
\text { group }\end{array}$ & control group \\
\hline $\begin{array}{l}\text { Alanine } \\
\text { transaminase, IU }\end{array}$ & $126.3 \pm 6.1$ & $139.3 \pm 1.9$ & $97.0 \pm 1.6^{*}$ & $83.3 \pm 1.1$ \\
\hline $\begin{array}{l}\text { Aspartate } \\
\text { transaminase, IU }\end{array}$ & $565.6 \pm 30.7$ & $612.3 \pm 57.9$ & $537.0 \pm 50.1$ & $527.6 \pm 71.6$ \\
\hline $\begin{array}{l}\text { Alkaline } \\
\text { phosphatase, IU }\end{array}$ & $864.0 \pm 16.2 *$ & $755.0 \pm 31.3$ & $792.3 \pm 45.3$ & $969.0 \pm 73.9$ \\
\hline $\begin{array}{l}\text { Lactate } \\
\text { dehydrogenase, IU }\end{array}$ & $2496.3 \pm 203.2$ & $2996.3 \pm 79.9$ & $10199.0 \pm 102.7$ & $10802.0 \pm 488.1$ \\
\hline Glucose, $\mathrm{mM}$ & $20.7 \pm 1.2$ & $19.4 \pm 0.8$ & $17.8 \pm 0.6$ & $18.21 \pm 1.5$ \\
\hline Total protein, g/L & $39.3 \pm 1.9$ & $37.3 \pm 0.6$ & $31.0 \pm 0.4$ & $31.0 \pm 1.2$ \\
\hline
\end{tabular}

Note: ${ }^{*} \mathrm{P}<0.05$, the difference is significant compared with the control.

stomach, there are massive round-cell infiltrates (inflammatory), stasis (plethora) of blood vessels. The mineralization of keratin masses in the esophagus and at the same time an active reaction of the basal cells of the esophagus are noted.

The mucous membrane of the stomach was rejected into the lumen with stick necrosis fragments of the glandular epithelium and the storage of individual Brunner glands, which are represented by a cylindrical epithelium. The rejection of the gastric mucosa extends to the limit of its plate. The last thinned, homogeneous, poor cells with signs of mineralization. The muscular membrane is thinned with signs of intermuscular edema; smooth muscle cell response and lymphocyte infiltration. Some preparations have no structural changes. All layers of the structure are clearly recognizable: lobes, fossa of the mucosa, and own glands. The submucosa of the mucosa membrane is thinned, the muscle and serous membranes are thickened.

The small intestine corresponds to the structure of the duodenum. The structure of the mucous membrane is preserved, despite the rejection of the mucous layers in the intestinal lumen and necrosis of a part of the villi. The submucosa and serous membrane are absent. In the stroma of the intestinal villi, lymphocytic infiltration is expressed. The structure of the small intestine is not broken in all layers. The villi of the mucous membrane are large with a moderate endothelial reaction. The cavernous expansion of the blood vessels of the submucosal layer is determined. Hypertrophied muscle plate (middle section). The serous membrane is absent.

In males, when studying the preparations in the transitional zone of the esophagus and the cardiac part of the stomach, the hyperkeratinization between the cells of the stratified squamous epithelium and the subepithelial layer with foci of mineralization (dystrophic liming) is noted. Massive foci of hemorrhage (intramuscular). The active reaction of nuclear forms of fat cells in the upper section. Fragmentation and decay of connective tissue fibers, which borders the squamous epithelium.

Transitional zone of the esophagus into the stomach: on the verge of a multilayer squamous epithelium of the esophagus and glandular epithelium of the cardiac section of the stomach, round-cell infiltrates were found. Dystrophic liming in the intermediate tis- 
sue of the esophagus. The structure of the stomach corresponds to the structure of the normal mucous membrane with pyloric glands and muscle membrane.

Small intestine: pockets crypts are clearly distinguished, villi are flattened, sent by a single-layer cylindrical epithelium, without visible pathological changes, mainly edged in the absence of other cells that make up the intestinal villus (goblet-like mucus-producing and endocrine-hormone-producing). Edema of the intermediate tissue of the Brunner glands with microcenters of inflammatory round-cell infiltrates was revealed.

When studying the transition of the esophagus to the cardiac stomach in males and females of the control group, the pattern of changes corresponds to the characteristic changes for the experimental group described above, with the difference that a more pronounced inflammatory reaction is noted in the underlying connective tissue stroma of the esophagus. It turns dystrophic liming subepithelial tissue of the esophagus. The cardiac glands of the esophagus (Brunner) are not structurally altered; there is intra-plasmic retardation of mucus with infiltration of the submucosal layer of lymphocyte.

In the plate of the mucous membrane of the esophagus, the structure is not broken, it contains all types of cells with a predominance of mucus-producing. In structure, it does not differ from the mucous membrane, characteristic for normal. In the small intestine, high villi were detected with a pronounced reaction of lymphocytes and plasma cells in their plate of the mucous membrane.

\section{Conclusions and Prospects}

During the feeding mice of the CBA line with the liposomal form of BAA "FLP-MD" based on milk phospholipids (within 16 days), a significant increase in body weight was observed after the 10th day of the experiment in both males and females. The amount of feed consumed during the entire period of the experiment in the control and experimental groups do not differ.

The obtained biochemical blood parameters indicate the absence of toxic effects of the liposomal form of BAA "FLP-MD" based on milk phospholipids on the functional condition of the body.

The morphological parameters of the peripheral blood in experimental animals receiving the liposomal form of BAA "FLP-MD" do not change significantly, with the exception of a decrease in the number of red blood cells and the ESR in animals of the experimental group.

According to the results of microscopic studies, there was no negative effect of the liposomal form of BAA "FLP-MD" based on milk phospholipids on the microstructures of the mucous membrane of the organs of the gastrointestinal tract. The normal structure of this section of the digestive tract is distinguished only by pronounced inflammatory infiltration (squamous) in the submucosal layer. Hyperplasia of the lymphoid elements of Peyer's plaques is noted. The epithelial cells of the Brunner glands are filled with mucus (delayed withdrawal), like the glands of the cardiac section of the stomach.

Therefore, the BAA "FLP-MD" can be recommended for use in veterinary medicine as a means of rehabilitation therapy.

\section{References}

Bothra, A., Arumugam, P., Panchal, V., Menon, D., Srivastava, S., Shankaran, D., Nandy, A., Jaisinghani, N., Singh, A., Gokhale, R. S., Gandotra S., \& Rao V. (2018). Phospholipid homeostasis, membrane tenacity and 
survival of Mtb in lipid rich conditions is determined by MmpL11 function. Scientific Reports, 8(8317):1-14. doi: 10.1038/ s41598-018-26710-z

Calitz, C., Hamman, J. H., Fey, S. J., Wrzesinski, K., \& Gouws, C. (2018). Recent advances in three-dimensional cell culturing to assess liver function and dysfunction: from a drug biotransformation and toxicity perspective. Toxicology Mechanisms and Methods, 28(5):369-385. doi: 10.1080/15376516.2017.1422580

Colombo, S., Melo, T., Martinez-Lopez, M., Carrasco, M. J., Domingues, P., Pérez-Sala, D., \& Domingues, R. (2018). P-150 - Phospholipidome of endothelial cells shows a different adaptation response upon oxidative, glycative or carbonyl stress. Free Radical Biology and Medicine, 120(1):S90. doi: 10.1016/j.freeradbiomed.2018.04.297

Gariani, K., Ryu, D., Menzies, K. J., Yi, H.-S., Stein, S., Zhang, H., Perino, A., Lemos, V., Katsyuba, E., Jha, P., Vijgen, S., Rubbia-Brandt, L., Kim, Y. K., Kim, J. T., Kim, K. S., Shong, M., Schoonjans, K., \& Auwerx1, J. (2017). Inhibiting poly ADP-ribosylation increases fatty acid oxidation and protects against fatty liver disease. Journal of Hepatology, 66(1):132-141.

Gryshchenko, V. A. (2019). Blood and acid composition of blood and biles in calves at enteropatology and application of milk phospholipides. Ukrainian Journal of Veterinary Sciences, 10(4):36-42, doi: 10.31548/ ujvs2019.04.005 (in Ukrainian).

Gryshchenko V., Danchenko O., \& Musiychuk V. (2019) Modification of Modeling Method of Toxic Dystrophy of Liver in Rats. In: Nadykto V. (eds) Modern Development Paths of Agricultural Production. Springer, Cham. doi: 10.1007/978-3-030-14918-5_67

Gryshchenko V. A., Sysolyatin S. V., \& Gulevata J. V. (2018). Phospholipid composition of blood plasma and internal organs of rats with diclofenac-induced hepatitis. Ukrainian Journal of Ecology, 8(3):211-215. Gryshchenko, V., Sysoliatin, S., \& Midyk, S. (2019). Fatty acids of lipids of blood serum and liver of rats with tetracyclin-induced hepatosis and at correction. Regulatory Mechanisms in Biosystems, 10(4):520-525. doi: 10.15421/021976

Gula, N. M., \& Margitich, V. M. (2009). Zhyrni kysloty ta yikh pokhidni pry patolohichnykh stanakh [Fatty acids and their derivatives in pathologic starts]. Naukova dumka, Kyiv (in Ukrainian).

Melnychuk, D. O., Gryshchenko, V. A., \& Lytvynenko, O. N.: Veterynarna biologichno aktyvna dobavka liposomal'noi' formy ta sposib reparatyvnoi' terapii' $v$ gepatologii' [Veterinary biologically active additive of liposomal form and method of reparative therapy in hepatology]. Patent UA, 86516 (2009). (in Ukrainian).

Sang-Chul, K. \& Xuemin, W. (2020). Phosphatidic acid: an emerging versatile class of cellular mediators. Essays in Biochemistry. EBC20190089. doi: 10.1042/EBC20190089

Solís-Calero, C., Ortega-Castro, J., Frau, J. \& Muñoz, F (2015). Nonenzymatic reactions above phospholipid surfaces of biological membranes: reactivity of phospholipids and their oxidation derivatives. Oxidative Medicine and Cellular Longevity, 319505:22. doi: 10.1155/2015/319505

Starr, M. L., Sparks, R. P., Arango, A. S., Hurst, L. R., Zhao, Z., Lihan, M., Jenkins, J. L. Tajkhorshid, E., \& Fratti, R. A. (2019). Phosphatidic acid induces conformational changes in Sec18protomers that prevent SNARE priming. Journal of Biological Chemistry, 294:31003116, doi: 10.1074/jbc.RA118.006552

Tomchuk V., Gryshchenko, V., Vlizlo, V., \& Enciu V. (2019). Corrective effect of milk phospholipids in pathological conditions. laşi Editura Ion Ionescu de la Brad.

Udut, V. V., Vengerovsky, A. I., \& Dygai, A. M. (2013). Effects of phospholipid hepatoprotectors on apoptosis during experimental liver pathology induced by isoniazid and paracetamol. Bulletin of Experimental Biology and Medicine, 154(5):614-617. doi: 10.1007/s10517-013-2012-9 
Vlizlo, V. V., Fedoruk, R. S., \& Ratych, I. B. (2012). Laboratorni metody doslidzhen u biolohiyi, tvarynnytstvi ta veterynarniy medytsyni [Laboratory methods of investigation in biology, stock-breeding and veterinary]. Spolom, Lviv (in Ukrainian).

Yang, K. J., Son, J., Jung, S. Y., Yi, G., Yoo, J., Kim, D. K., \& Koo, H. (2018). Optimized phospholipid-based nanoparticles for inner ear drug delivery and therapy. Biomaterials,
171(7):133-143. doi: 10.1016/j.biomaterials.2018.04.038

Zhang, X., Yang, L., Liu, Y., Song, Z., Zhao, J., Chen, D., Yu, H., Li, R., Wang, Y., Yang, K., Chen, Y., Xia, M., \& Zhang, L. W. (2018). Detection of nanocarrier potentiation on drug induced phospholipidosis in cultured cells and primary hepatocyte spheroids by high content imaging and analysis. Toxicology and Applied Pharmacology, 348:54-66. doi: 10.1016/j.taap.2018.04.016

\section{В. А. Грищенко (2020). ВПЛИВ ФОСФОЛІПІДОВМІСНОї БІОДОБАВКИ НА ФУНК- ЦІОНАЛЬНИЙ СТАН ОРГАНІВ ТА СИСТЕМ ОРГАНІЗМУ МИШЕЙ. Ukrainian Journal}

of Veterinary Sciences, 11(3): 14-23, https://doi.org/10.31548/ujvs2020.03.002

Анотація. Численними дослідженнями в експериментах на лабораторних тваринах і під час використання в клінічній практиці підтверджено позитивний вплив есенційних фосроліпідів на структурну організацію клітинних мембран, внутрішньоклітинний метаболізм, функціональну здатність мітохондрій, антиоксидантні процеси, що пояснює активне застосування фосфоліпідовмісних препаратів за гепато- та ентеропатологій, серцево-судинних захворювань тощо. Структурну подібність із фосфоліпідами тканин ссавців має сировина тваринного походження, зокрема, молока, яка є безпечним джерелом біологічно активних речовин. На їхній основі створено біологічно активну добавку (БАД) «FLP-MD», для якої характерні мембранотропні властивості та репаративний ефект дії. Метою роботи було дослідити біологічний вплив ліпосомальної форми БАД «FLP-MD» на основі фосфоліпідів молока на організм клінічно здорових лабораторних мишей.

Визначення токсичності фосфоліпідовмісної БАД «FLP-MD» проводили на мишах лінії СВА. Тривалість досліду становила 16 діб. Результати досліджень свідчать про вірогідне збільшення маси тіла мишей лінії СВА після 10-ої доби інтрагастрального введення 1\% розчину ліпосомальної форми БАД «FLP-MD».

У результаті дослідження біохімічних показників плазми/нативної крові встановлено відсутність токсичного впливу ліпосомальної форми БАД «FLP-MD» на функціональний стан організму мишей. Морфологічні показники перифреричної крові иих тварин не зазнавали істотних змін. За результатами мікроскопічних досліджень не виявлено негативного впливу ліпосомальної форми БАД «FLP-MD» на мікроструктуру слизової оболонки органів шлунково-кишкового тракту.

Отже, складові БАД «FLP-MD» не чинять негативного впливу на функціональний стан органів і систем організму лабораторних мишей та не виявляють токсичного ефекту дії, що дозволяє їі рекомендувати для застосування у ветеринарії в якості засобу відновлювальної терапії.

Ключові слова: фосфоліпіди молока, БАД «FLP-MD», лабораторні миші лінії CBA, клінічні, гематологічні та мікроскопічні дослідження, функціональний стан організму 